Sains Malaysiana 49(1)(2020): 139-143

http://dx.doi.org/10.17576/jsm-2020-4901-17

\title{
Effectiveness of Pre-Procedural Rinsing with Essential Oils-Based Mouthrinse to Reduce Aerosol Contamination of Periodontitis Patients
}

(Keberkesanan Berkumur menggunakan Bahan Kumur Berasaskan Minyak Pati untuk Mengurangkan Pencemaran Aerosol dalam Kalangan Pesakit Periodontitis)

\author{
A.S. Sadun*, T.B. Taiyeb-Ali, A.R. Fathilah, W.H. Himratul-Aznita, R. Saub, S.H. Safil \& \\ Z.A. Che Aв AzIZ
}

\section{ABSTRACT}

This research aims to evaluate the effectiveness of pre-procedural rinsing using essential oils-mouthwash (Listerine ${ }^{\circledR}$ ) in reducing bioaerosol contamination in a dental clinic. Thirty (30) subjects who consisted of those receiving treatment for periodontitis problems were randomly assigned to rinse with either $20 \mathrm{~mL}$ of Listerine ${ }^{\circledR}$ or $20 \mathrm{~mL}$ of placebo as control rinse. Every subject was instructed to gargle using the rinse for $1 \mathrm{~min}$. Microbial samples of environmental air and saliva were collected before and after the rinse. All samples were further analyzed for total plate counts to measure the microbial level. Rinsing using Listerine ${ }^{\circledR}$ showed significant reduction in the level of microbial load in saliva compared to the control mouthrinses. Analysis done at three defined distance intervals from the operating site showed the level of bioaerosol contamination was highest at distance nearest to the treatment point of $1 \mathrm{ft}$. Based on counts of $c f u$, there was higher presence of microbial contaminant in bioaerosols of the control-rinsed group compared to the testrinsed group using Listerine ${ }^{\circledR}$. Therefore, it can be concluded that rinsing using Listerine ${ }^{\circledR}$ was effective towards reducing the microorganisms in saliva and oral cavity in general.

Keywords: Biolog; essential-oils; Listerine ${ }^{\circledR}$; microorganisms; mouthrinse; saliva

ABSTRAK

Kajian ini bertujuan untuk menilai keberkesanan berkumur menggunakan bahan kumur berasaskan minyak pati (Listerine $^{\circledR}$ ) dalam mengurangkan pencemaran bioaerosol di klinik pergigian. Tiga puluh (30) subjek yang terdiri daripada penerima rawatan untuk masalah periodontitis dipilih secara rawak untuk berkumur menggunakan sama ada 20 mL Listerine ${ }^{\circledR}$ atau 20 mL plasebo sebagai kumuran kawalan. Setiap subjek diarahkan untuk berkumur selama 1 minit. Sampel mikrob pada persekitaran udara dan air liur dikumpulkan sebelum dan selepas berkumur. Semua sampel seterusnya dianalisis untuk menentukan tahap kandungan mikrobnya. Kumuran menggunakan Listerine ${ }^{\circledR}$ menunjukkan pengurangan ketara terhadap pencemaran mikrob dalam air liur berbanding dengan kumuran menggunakan plasebo sebagai kawalan. Analisis tahap pencemaran pada tiga jarak yang ditetapkan daripada punca rawatan menunjukkan pencemaran bioerosol paling tinggi pada jarak yang paling dekat kepada punca rawatan iaitu 1 kaki. Berdasarkan kiraan cfu, lebih banyak mikrob pencemar didapati dalam bioerosol terhasil daripada kumpulan kawalan daripada kumpulan ujian yang menggunakan Listerine ${ }^{\circledR}$. Sebagai kesimpulan, kumuran sebelum prosedur menggunakan bahan kumur Listerine $e^{\circledR}$ adalah berkesan dalam mengurangkan penyebaran mikroorganisma dalam bioaerosol yang terhasil ketika prosedur rawatan, air liur dan kaviti oral keseluruhannya.

Kata kunci: Air liur; bahan kumur; biolog; Listerine ${ }^{\circledR}$; mikroorganisma; minyak pati

\section{INTRODUCTION}

The humidity and temperature of the oral cavity create a wide range of microbial habitats with different environmental conditions suitable for growth and colonization of various types of microorganisms (Marsh $\&$ Martin 2009). Oral microbes comprise various groups of microorganisms including bacteria, fungi, mycoplasma, protozoa, and viruses. It has been reported that at least 750 different types of bacteria reside in the oral cavity (Jenkinson \& Lamont 2005; Paster et al. 2006) and about 150 billion and 6 billion microorganisms were reported to be present in $1 \mathrm{~mL}$ of gingival crevicular fluid (GCF) and saliva, respectively (Checchi et al. 1992). Although reports of cross-contamination are rare, dental health professionals are at high risk for developing infectious diseases because of the repeated exposures to these microorganisms while working in a dental clinical setting (King et al. 1997). The possible sources of airborne contamination during dental treatment are dental instruments, saliva, respiratory sources and the operative sites.

Transmission of microorganisms from person to person or cross contamination may occur by direct contact 
with contaminated tissues and instruments or by aerosols containing infectious agents. The spread of infection has long been considered as one of the main concerns in the dental community. Infectious agents may be transmitted to patients and dental staff via several vectors, including instruments and aerosol. There is a long history of infections being transmitted by an airborne route, and the potential of this route was recognized even before the discovery of specific infectious agents such as bacteria and viruses. Based on the infectious status of a person, the bioaerosols are proven to contain influenza or rhinoviruses, Mycobacterium tuberculosis, Staphylococcus aureus, Varicella Zoster Virus, Streptococcus spp. or Aspergillus spp. (Zemouri et al. 2017).

The incorporation of essential oils in Listerine ${ }^{\circledR}$ is to provide an alternative mouthrinse that could match the antimicrobial activity of mouthrinse with chlorhexidine active compound. This is because chlorhexidine was reported to cause side effects such as pigmentation, taste alteration, ulceration and the formation of supragingival calculus with long-term use (Flötra et al. 1971). The effectiveness of essential oils in Listerine ${ }^{\circledR}$ has long been debated. It is argued that it is the alcohol in the mouthrinse that causes the bactericidal effect. The alcohol (ethanol) present in Listerine ${ }^{\circledR}$ is only to dissolve the numerous substances in the mouthrinse including to solubilize the active agents (essential oils). In fact, the concentration of alcohol in Listerine ${ }^{\circledR}$ is only about $20 \%$ which is not enough to perform direct bactericidal activity (Marchetti et al. 2009).

Therefore, since essential oils is known to be a safer alternative antimicrobial agent in mouthwash, this study was to evaluate the effectiveness of pre-procedural rinsing with essential oils-based mouthwash in reducing aerosol contamination in a dental clinical setting during dental procedures, as well as to isolate and identify microbial contaminants in bioaerosol produced during treatment periodontal patients.

\section{Materials AND Methods}

\section{MOUTHWASH PREPARATION}

Two types of mouthwashes were prepared for use during sample collection; Test mouthwash which is the actual essential oil-based Listerine ${ }^{\circledR}$, and Placebo/Control mouthwash prepared to resemble the exact colour of Listerine ${ }^{\circledR}$ by mixing sterile distilled water and dye. Preparation of mouthwashes was performed within a Biological cabinet to ensure cleanliness and sterility.

\section{TEST MOUTHWASH}

Twenty (20) mL of Listerine ${ }^{\circledR}$ (Johnson \& Johnson) was pipetted into 30 sterile Universal bottles and properly sealed to avoid contamination.

\section{PLACEBO/CONTROL MOUTHWASH}

One (1) L of distilled water was sterilized by autoclaving and several drops of green and blue food dyes were added produce a mixture with colour that resembles Listerine ${ }^{\circledR}$ mouthwash. $20 \mathrm{~mL}$ of the placebo was then pipetted into 30 sterile Universal bottles and properly sealed to avoid contamination.

\section{SAMPLING TeChNiQue}

Thirty (30) subjects who consisted of those receiving treatment for periodontal problems were randomly assigned to pre-rinse with either $20 \mathrm{~mL}$ of Test mouthwash (Listerine ${ }^{\circledR}$ ) or $20 \mathrm{~mL}$ of Placebo mouthwash (coloured distilled water). Prior to sampling, every subject was asked to fill in the consent form with attached copy of ethic approval and was also briefed on the whole process. Every subject was instructed to gargle using the mouthwash for 1 min prior to dental scaling treatment procedure. All subjects are non-diabetic patients. Of the 30 subjects, 20 patients were with moderate periodontitis and another 10 patients were with advanced periodontitis. This was confirmed by the operator who carried out the treatment. Subjects were divided into 2 groups which were the test and control groups. The patient and the operator were blinded to the type of mouthwash used.

\section{SAMPle Collection}

Samples collected include the patient's saliva and aerosol generated during scaling treatment. All these sample types were collected prior and after rinsing using the assigned mouthwash.

\section{SALIVA SAMPLES}

Prior to rinsing, patients were requested to spit out their saliva over a duration of $1 \mathrm{~min}$ into a sterile Universal bottle. Following that they were asked to gargle using the assigned mouthwash for $1 \mathrm{~min}$. Another saliva sample was collected into a fresh universal bottle immediately after the rinse, over a period of $1 \mathrm{~min}$. All bottles were placed in ice and transported to the laboratory for further processing.

\section{AEROSOL SAMPLES}

Aerosols were sampled from three different points specified as: $1 \mathrm{ft}(30.48 \mathrm{~cm}), 2 \mathrm{ft}(60.96 \mathrm{~cm})$ and $3 \mathrm{ft}(91.44 \mathrm{~cm})$ from the scaling treatment site (patient's mouth). For standardization purpose, a collection stand was designed to hold Brain Heart Infusion (BHI) media plates in triplicate Petri dishes at the three designated positions. An exposure period of $1 \mathrm{~min}$ could capture the aerosols generated during the treatment procedure of each patient. Collection of aerosol samples were made prior and during the treatment procedure. 
MEASUREMENT OF OPERATOR-PATIENT AND ASSISTANTPATIENT DISTANCE

The measurement of operating distances between the Operator-Patient and Assistant-Patient was done at the treatment clinic. An average of 15 Operator-Patient and Assistant-Patient distances were measured during 15 treatment appointments. The measurement was done to co-relate the average distance of Operator-Patient and Assistant-Patient with the possible risk of exposure to bioaerosols based on the outcome of the study which is by looking at the number of microbial colonies in the aerosols captured at the three different measured distances during the sampling process

\section{TOTAL PLATE COUNT (TPC)}

Based on the standard microbiological method, saliva samples were serially diluted from $10^{-1}$ down to $10^{-6}$ and spread plate of the dilution factor $10^{-3}, 10^{-4}$ and $10^{-5}$ was done in triplicates on BHI agar. The plates were then incubated for $24 \mathrm{~h}$ at $37^{\circ} \mathrm{C}$. Plates of aerosol samples were also incubated under similar condition and the total colony counts were enumerated and recorded. The difference in colony forming unit (cfu) counts between the pre-rinse and post-rinse samples was calculated to indicate the population of microorganisms effectively eliminated from the oral surfaces and aerosol following gargling with the test and placebo mouthwashes.

\section{STATISTICAL DATA ANALYSIS}

Data analysis was done to evaluate the significant difference ( $p$-value) in terms of cfu numbers in both aerosols and saliva after rinsing with Control and Test mouthwash. Independent sample t-test was used in statistical analysis of the microbiology data using SPSS Statistical Software.

\section{RESULTS}

EFFECT OF PRE-PROCEDURAL RINSING USING CONTROL OR TEST MOUTHWASH (LISTERINE) ON MICROBIAL LOAD OF SALIVA SAMPLES

Table 1 shows the comparison of total microbial load (cfu/ $\mathrm{mL}$ ) in saliva of test and control groups of periodontitis $(\mathrm{N}=30)$ patients. The reduction of microbial load after rinse is represented in mean percentage reduction (\%). The test

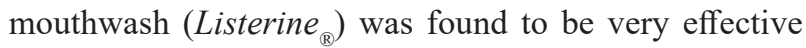
causing a reduction in microbial load of saliva samples by $89.33 \%(p<0.05)$ compared to control mouthwash. The control mouthwash only reduces the microbial by $34.26 \%$.

EFFECT OF PRE-PROCEDURAL RINSING ON PERIODONTITIS PATIENTS USING CONTROL AND TEST MOUTHWASH (Listerine $^{\circledR}$ ) ON MICROBIAL CONTAMINANT OF BIOAEROSOL PRODUCED

In general, the population of microorganisms present in bioaerosol produced while patients were receiving dental treatment was rather low (Table 2). Based on the mean cfu counts, patients pre-rinsed using Listerine ${ }^{\circledR}$ showed significantly reduced presence of microbial contaminants compared to those pre-rinsed using the control mouthwash. Listerine ${ }^{\circledR}$ effectively reduced the presence of contaminant in the bioaerosol by $86.4 \%$.

EFFECT OF PRE-PROCEDURAL RINSING USING CONTROL AND TEST MOUTHWASHES ON THE CONCENTRATION OF MICROBIAL CONTAMINANT IN BIOAEROSOL SAMPLED AT THREE DISTANCES FROM THE POINT OF TREATMENT

The presence of microbial contaminant in bioaerosol varies at different distances from the point of treatment. Higher number of counts was recorded at distance nearest to the treatment point while the degree of contamination showed a decrease moving away from the point of treatment (Table $3)$. This observation was made both following preprocedural rinsing with the control and test groups. Although both the control and Listerine ${ }^{\circledR}$ mouthwashes were able to significantly reduce the presence of contaminants in bioaerosols, the result of pre-rinsing using Listerine ${ }^{\circledR}$ was more effective.

\section{OPERATOR-PATIENT AND ASSISTANT-PATIENT DISTANCE}

The distance between the operator (face) and patient (mouth) observed during fifteen dental treatment procedures was about $0.8 \mathrm{ft}(24.38 \mathrm{~cm})$, while distance of dental assistance from the patient was about $1.3 \mathrm{ft}(39.62$ cm) (Table 4).

\section{DISCUSSION}

Aerosols contamination has been a concern in medical and dental fields due to its ability to cause cross contamination or cross infection especially during treatments. The sources

TABLE 1. The mean percentage reduction in microbial load between the test and control groups of periodontitis saliva samples using independent sample t-test

\begin{tabular}{lccccc}
\hline \multirow{2}{*}{$\begin{array}{l}\text { Sample } \\
\text { Mouthwash }\end{array}$} & $\mathrm{N}$ & \multicolumn{2}{c}{$(\times 107) \mathrm{cfu} / \mathrm{mL}$} & Mean Reduction \pm Std Dev $(\%)$ & $\mathrm{p}$-value \\
\hline \multirow{2}{*}{ Periodontitis } & Control & 15 & 11.48 & 7.55 & $34.26 \pm 11.08$ \\
& Test (Listerine $(\mathbb{R})$ & 15 & 12.81 & 1.42 & $89.33 \pm 4.24$ \\
\hline
\end{tabular}


TABLE 2. Comparison of overall mean differences between test and control groups in bioaerosols from the periodontitis treatment group using independent sample t-test

\begin{tabular}{lccccccc}
\hline Sample & Control & & & Test & \multicolumn{2}{c}{ p-value } \\
& N & Mean & Std Dev & N & Mean & Std Dev & 0.011 \\
\hline Periodontitis & 15 & 1.32 & 0.32 & 15 & 0.18 & 0.12 & 0.12 \\
\hline
\end{tabular}

TABLE 3. Comparison of mean differences between test and control groups in bioaerosols from the periodontitis treatment group at three different distances using Independent sample t-test

\begin{tabular}{lcccccccc}
\hline \multirow{2}{*}{ Distance from treatment point (ft) } & \multicolumn{3}{c}{ Control } & \multicolumn{3}{c}{ Test } & Mean Difference (\%) & p-value \\
& N & Mean & Std Dev & N & Mean & Std Dev & & 0.029 \\
\hline $1 \mathrm{ft}(30.48 \mathrm{~cm})$ & 15 & 2.22 & 0.63 & 15 & 0.58 & 0.36 & $73 \%$ & 0.042 \\
$2 \mathrm{ft}(60.96 \mathrm{~cm})$ & 15 & 1.64 & 0.46 & 15 & 0.15 & 0.17 & $89 \%$ & 0.170 \\
$3 \mathrm{ft}(91.44 \mathrm{~cm})$ & 15 & 0.51 & 0.33 & 15 & 0.15 & 0.24 & $68 \%$ & 0 \\
\hline
\end{tabular}

TABLE 4. The operating distances between Operator-Patient and Assistant-Patient. Measurements were obtained during dental treatment at the students' dental clinic, University of Malaya Dental Centre (UMDC)

\begin{tabular}{lccc}
\hline & No. of measurements & Average distance & Range of distance \\
\hline Operator-Patient & 15 & $0.8 \mathrm{ft}(24.38 \mathrm{~cm})$ & $0.6 \mathrm{ft}(18.23 \mathrm{~cm})-1.2 \mathrm{ft}(36.58 \mathrm{~cm})$ \\
Assistant-Patient & 15 & $1.3 \mathrm{ft}(39.62 \mathrm{~cm})$ & $1.1 \mathrm{ft}(33.53 \mathrm{~cm})-1.8 \mathrm{ft}(54.86 \mathrm{~cm})$ \\
\hline
\end{tabular}

of contamination are normally from oral fluids and dental plaque which may contain many different species of microorganisms attached to one another. Some of these microorganisms could be pathogenic and may cause opportunistic infection once inhaled by the patients or anyone else who is exposed to the aerosols contamination (Suresh et al. 2011).

There are very few documented studies done to find the effectiveness of antiseptic mouthrinses in particularly essential oils-based mouthwashes in reducing bioaerosols contamination (Marchetti et al. 2009). Most of the studies in developed countries focused more on chlorhexidine as an antimicrobial agent as compared to other potential antiseptic agents. Therefore, this study was done on essential-oils based mouthwash (Listerine ${ }^{\circledR}$ ) as an antimicrobial agent and to investigate the effectiveness towards reducing bioaerosols contaminants during clinical treatment in dental clinic.

Listerine ${ }^{\circledR}$ contains bioactive compounds called essential oils found in mint, thyme, wintergreen and eucalyptus. These oils consist of Thymol $(0.064 \%)$, Eucalyptol (0.092\%), Methyl salicylate $(0.060 \%)$ and Menthol $(0.042 \%)$. These essential oils possess anti-plaque activity which causes the biofilms of microorganisms or dental plaques to disintegrate (Alshehri 2018). These essential oils also destroy microbial cell walls and inhibit microbial enzyme activities (Fine 1998). Therefore, Listerine $^{\circledR}$ is not only effective as an antiplaque agent, it is also effective in reducing the risk of gingivitis and periodontitis development (Overholser et al. 1990).

The average colony counts (TPC) for saliva samples was relatively like a previous study on microbial load
(Akande et al. 2004). It is relatively similar to the microbial load sampled from all the subjects' saliva. The microbial load in $1 \mathrm{~mL}$ of saliva ranged between $10^{6}$ and $10^{8}$ colony forming units (cfu $\mathrm{mL}^{-1}$ ). Rinsing with either placebo or Listerine ${ }^{\circledR}$ showed a significant difference in the comparison of the mean percentage reduction of microbial load in saliva before and after rinsing in both control and test groups. Serial dilution was done at three different dilution factors $\left(10^{-3}, 10^{-4}\right.$ and $\left.10^{-5}\right)$ and colony forming units per $\mathrm{mL}$ (cfu $\mathrm{mL}^{-1}$ ) was calculated. Percentage of microbial load reduction in saliva is referred. The reduction of the microbial load after rinse is represented in mean percentage $(\%)$. Periodontitis groups showed significant difference $(p<0.05)$ on comparison between the control and test groups in each. The average percentage reduction in microbial contaminant level with placebo (coloured distilled water) and test mouthwash in periodontitis treatment group were $34.26 \%$ and $89.33 \%$, respectively. A previous study showed a $33.9 \%$ reduction in the bacterial load after rinsing with distilled water as a mouthwash indicating that on rinsing with distilled water itself, a certain amount of microbial load can be washed away (Suresh et al. 2011). This was also observed in this study following rinsing with the control mouthwash (placebo).

On an average, an operator will normally work with a patient at a distance less than 1 (one) foot. Meanwhile, a dental assistant would normally be working at more than 1 (one) foot. With reference to the outcomes of the bioaerosols produced during treatment of patients, it can be expected that the operator will be exposed to a higher level of bioaerosols during treatment as compared to the assistant. 
Besides using face masks and eye protectors as the first barrier for cross-infection protection, pre-procedural rinsing can be an essential and the first cross-infection control measure to reduce the level of bioaerosols produced during dental treatments. From the outcomes of the present study, up to $87 \%$ of bioaerosols can be reduced after preprocedural rinsing with essential oils-based mouthwash. This can be an added protocol in dental clinics because of its effectiveness in reducing bioaerosols production during dental treatments as well as reducing the risk of crossinfections to the dental operator, chair-side assistant and other dental auxiliaries who are involved.

\section{CONCLUSION}

In this study, we found that pre-procedural rinsing using the essential oils-based mouthwash Listerine ${ }^{\circledR}$ was effective towards reducing the spread of microorganisms in oral bioaerosol generated during dental treatment procedures. This finding reinforces infection control with preprocedural rinsing using the essential oils-based mouthwash and should be introduced in dental clinics.

\section{ACKNOWLEDGEMENTS}

We are highly gratitude to the Faculty of Dentistry, University of Malaya for the research facilities. This work was supported by the University of Malaya PPP under Grant PG064-2014A; and Johnson \& Johnson (Malaysia) under Grant PPPC/C1-2012/DEGC/34. The authors declare that there is no conflict of interests regarding the publication of this paper.

\section{REFERENCES}

Akande, O., Alada, A., Aderinokun, G.A. \& Ige, A.O. 2004. Efficacy of different brands of mouthrinses on oral bacterial load count in healthy adults. African Journal of Biomedical Research 7(3): 125-128.

Alshehri, F.A. 2018. The use of mouthwash containing essential oils (LISTERINE®) to improve oral health: A systematic review. Saudi Dent. J. 30(1): 2-6.

Checchi, L., Trombelli, L. \& Nonato, M. 1992. Postoperative infections and tetracycline prophylaxis in periodontal surgery: A retrospective study. Quintessence International 23: 191-195.

Fine, D.H. 1998. Mouthrinses as adjuncts for plaque and gingivitis management. American Journal of Dentistry 1: 259-263.

Flötra, L., Gjermo, P., Rölla, G. \& Waerhaug, J. 1971. Side effects of chlorhexidine mouth washes. IOSR Journal of Dental and Medical Sciences 79(2): 119-125.

Jenkinson, H.F. \& Lamont, R.J. 2005. Oral microbial communities in sickness and in health. Trends in Microbiology 13(12): 589-595.

King, T.B., Muzzin, K.B., Berry, C.W. \& Anders, L.M. 1997. The effectiveness of an aerosol reduction device for ultrasonic scalers. Journal of Periodontology 68(1): 45-49.

Marchetti, E., Mummulo, S., Marzo, G., Civisca, A., Di Pietro, C. \& Marinelli, G. 2009. Effect of an essential- oil containing mouthrinse on the reduction of plaque and interproximal inflammation in comparison with an ethanol solution. Prev. Assist. Dent. 35(4): 123-127.

Marsh, P.D. \& Martin, M.V. 2009. Mouth as a microbial habitat. In Oral Microbiology Textbook, edited by Lewis, M.A. Edinburgh: Churchill Livingstone Elsevier. pp. 8- 23.

Overholser, C.D., Meiller, T.F., DePaola, L.G., Minah, G.E. \& Niehaus, C. 1990. Comparative effects of 2 chemotherapeutic mouthrinses on the development of supragingival dental plaque and gingivitis. Journal of Clinical Periodontology 17: 575-579.

Paster, B.J., Olsen, I., Aas, J.A. \& Dewhirst, F.E. 2006. The breadth of bacterial diversity in the human periodontal pocket and other oral sites. Periodontology 42: 80-87.

Suresh, S., Manimegalai, M. \& Sudhakar, U. 2011. Comparison of efficacy of preprocedural rinsing with chorhexidine and essential oil mouthwash in reducing viable bacteria in dental aerosols - A microbiological study. International Journal of Contemporary Dental and Medical Reviews 2: 6.

Tsai, H. \& Bobek, L.A. 1998. Human salivary histatins: Promising anti-fungal therapeutic agents. Critical Reviews in Oral Biology and Medicine 9(4): 480-497.

Zemouri, C., de Soet, H., Crielaard, W. \& Laheij, A. 2017. A scoping review on bio-aerosols in healthcare and the dental environment. PLOS ONE 2(5): 1-25.

A.S. Sadun* \& W.H. Himratul-Aznita

Department of Oral and Craniofacial Sciences

Faculty of Dentistry

University of Malaya

50600 Kuala Lumpur, Federal Territory

Malaysia

T.B. Taiyeb-Ali

Department of Periodontology

Faculty of Dentistry

MAHSA University, Saujana Putra

42610 Jenjarom, Selangor Darul Ehsan

Malaysia

A.R. Fathilah

Faculty of Dental Medicine

Airlangga University, Surabaya

Indonesia

\section{R. Saub}

Department of Community Oral Health \& Clinical Prevention

Faculty of Dentistry

University of Malaya

50600 Kuala Lumpur, Federal Territory

Malaysia

\section{S.H. Safii \& Z.A. Che Ab Aziz}

Department of Restorative Dentistry

Faculty of Dentistry

University of Malaya

50600 Kuala Lumpur, Federal Territory

Malaysia

*Corresponding author; email: asyrafulsabqisadun@gmail. com

Received: 26 February 2019

Accepted: 22 October 2019 